\title{
KAJIAN FISIKOKIMIA DAN SENSORI SNACK BARS TEMPE BAGI PENDERITA AUTIS
}

\section{PHYSICOCHEMICAL AND SENSORY CHARACTERISTIC STUDY OF TEMPEH SNACK BARS TO AUTISTIC}

\author{
Windi Atmaka, Nur Her Riyadi Parnanto, Rohula Utami ${ }^{1)}$ \\ ${ }^{1)}$ Program studi Ilmu dan Teknologi Pangan Fakultas Pertanian Universitas Sebelas Maret
}

Email: atmaka.windi@yahoo.com

\begin{abstract}
This research activity was done with three steps. They were tempeh flour production, dried fruit production, tempeh snack bars production and physicochemical and sensory analysis. Snack bars formula consists of three variations. They were comparison between tempeh flour and dried fruit (40:60, 50:50 and 60:40). Dried fruits were used are mango and snake fruit. The results showed that the hardness level of tempeh snack bars was higher with the increasing of tempeh flour proportion. Moisture content of snack bars was lower with the increasing of tempeh flour proportion except snack bars with snake fruit. Ash content was also higher with the increasing of tempeh flour proportion. Protein content and fat content were higher with the increasing of tempeh flour proportion. Carbohydrate content was lower with the increasing of tempeh flour proportion. Dietary fiber content and total phenol compound weren't different significantly. Antioxidant activity was higher with the increasing of tempeh flour proportion. Based on overall parameters, snack bars which had the highest evaluation value from panelist were snack bars with mango fruit 40:60, and snake fruit 60:40.
\end{abstract}

Key words: autistic, dried fruit, physicochemical, snack bars, tempeh flour

\begin{abstract}
ABSTRAK
Kegiatan penelitian ini dilakukan dengan beberapa tahap yaitu tahap pembuatan tepung tempe, tahap pembuatan buah kering, tahap pembuatan snack bars tempe, serta tahap analisa fisikokimia dan sensori. Formula snackbars terdiri dari 3 variasi yaitu perbandingan antara tepung tempe dan buah kering sebesar 40:60, 50:50 dan 60:40. Buah kering yang digunakan adalah mangga dan salak. Berdasarkan hasil penelitian diketahui bahwa tingkat kekerasan tekstur snack bars semakin tinggi dengan semakin besarnya proporsi tepung tempe. Kadar air snack bars semakin rendah dengan semakin besarnya proporsi tepung tempe kecuali snack bars dengan campuran buah salak. Kadar abu snack bars semakin tinggi dengan semakin besarnya proporsi tepung tempe. Kadar protein snack bars semakin besar dengan semakin besarnya proporsi tepung tempe. Kadar lemak snack bars semakin besar dengan semakin besarnya proporsi tepung tempe. Kadar karbohidrat snack bars semakin rendah dengan semakin besarnya proporsi tepung tempe. Kadar serat dan total fenol snack bars tidak berbeda nyata antar variasi sampel. Aktivitas antioksidan snack bars semakin besar dengan semakin besarnya proporsi tepung tempe. Total kalori snackbars semakin besar dengan semakin besarnya proporsi tepung tempe. Berdasarkan parameter overall, snack bars yang mendapatkan penilaian tertinggi dari panelis adalah snack bars dengan campuran mangga 40:60 dan salak 60:40.
\end{abstract}

Kata kunci : autis, buah kering, snack bars, sifat fisikokimia, tepung tempe

\section{PENDAHULUAN}

Autis adalah gangguan perkembangan pada anak yang ditandai dengan adanya gangguan dan keterlambatan dalam bidang kognitif, bahasa, perilaku, komunikasi, interaksi, sosial dan gangguan persepsi sensori. Jumlah penyandang autis semakin meningkat pesat dalam dekade terakhir ini.

Para ahli sepakat bahwa sebaiknya anak autis melakukan diet gluten dan kasein atau CFGF (Casein Free Gluten Free). Adam (2007) melaporkan salah satu cara tindakan biomedis terhadap penyandang autis adalah melalui diet CFGF. Selain diyakini memperbaiki gangguan pencernaan, diet ini juga bisa mengurangi gejala atau tingkah laku autistik. Gluten dan kasein adalah protein, sedangkan protein merupakan zat gizi yang penting bagi pembentukan sel-sel baru. Menghilangkan asupan kedua jenis protein ini dapat membuat anak kekurangan protein. Oleh karena itu diperlukan asupan protein jenis lain, seperti protein nabati dari kacangkacangan antara lain kedelai.

Kedelai merupakan salah satu kacangkacangan yang dapat digunakan sebagai sumber protein. Biji kedelai terdiri dari 7,3 persen kulit, 90,3 persen kotiledon (isi atau 
"daging" kedelai) dan 2,4 persen hipokotil. Kedelai mengandung protein rata-rata 35 persen, bahkan dalam varietas unggul kandungan proteinnya dapat mencapai 40 44 persen. Protein kedelai sebagian besar (85 - 95 persen) terdiri dari globulin dan dibandingkan dengan kacang-kacangan lain, susunan asam amino pada kedelai lebih lengkap dan seimbang. Selain itu kedelai juga dapat diunakan sebagai sumber serat, vitamin, dan mineral (Santoso, 2005).

Disamping mengandung senyawasenyawa yang bermanfaat, ternyata pada kedelai juga terdapat senyawa-senyawa anti gizi dan senyawa penyebab off - flavor (penyimpangan cita rasa dan aroma pada produk pengolahan kedelai). Diantara senyawa anti gizi yang sangat mempengaruhi mutu produk olahan kedelai ialah antitripsin, hemaglutinin, asam fitat, oligosakarida penyebab flatulensi (timbulnya gas dalam perut sehingga perut menjadi kembung). Sedangkan senyawa penyebab "off flavor" pada kedelai ialah glukosida, saponin, estrogen dan senyawa - senyawa penyebab alergi. Dalam pengolahan, senyawa-senyawa tersebut harus dihilangkan, atau diinaktifkan, sehingga akan dihasilkan produk olahan kedelai dengan mutu terbaik dan aman untuk dikonsumsi manusia. Untuknya proses penghilangan senyawa-senyawa pengganggu ini tidak sulit salah satunya dengan cara fermentasi dengan mengolah kedelai menjadi tempe (Santoso, 2005).

Tempe mengandung komponenkomponen gizi yang tinggi seperti protein dan vitamin B12 (Kasmidjo, 1996). Astuti et.al (2000) juga melaporkan bahwa tempe merupakan sumber protein, vitamin B12, antioksidan, fitokimia dan senyawa bioaktif lainnya. Beberapa studi juga mengindikasikan bahwa tempe mempunyai keuntungan positif terhadap kesehatan nilai gizi dan kesehatan. Beberapa penelitian menunjukkan bahwa zat gizi tempe lebih mudah dicerna, diserap dan dimanfaatkan tubuh dibandingkan dengan yang ada dalam kedelai (Astawan, 2003). Namun, pada umumnya tempe termasuk bahan makanan yang mudah rusak. Masa simpan tempe segar hanya selama 2-3 hari pada suhu ruang. Setelah melewati masa itu enzim proteolitik akan merombak protein tempe sehingga tempe menjadi busuk (Sarwono 1988). Oleh karena itu perlu teknologi yang mampu meningkatkan periode kemanfaatan tempe, salah satunya dengan pengolahan tepung tempe.

Tempe yang ditepungkan mempunyai kemungkinan lebih luas untuk dikonsumsi, dapat disimpan lebih lama dan lebih awet dibanding tempe segar (Kasmidjo, 1990). Menurut Sarwono (1988), tepung tempe dapat ditambahkan pada makanan lain tanpa merubah citarasa makanan yang ditambahkan. Kandungan gizi tepung tempe antara lain protein $46,1 \%$, lemak $22,7 \%$, karbohidrat $10,1 \%$, serat makanan $1,4 \%$ dan vitamin E 39,4 mg/100g. Tepung tempe juga mengandung sejumlah mineral antara lain $\mathrm{P}, \mathrm{Na}, \mathrm{Mg}, \mathrm{Na}, \mathrm{Fe}, \mathrm{Cu}$ dan $\mathrm{Zn}$ (LIPI, 2001). Tepung tempe telah digunakan sebagai bahan dalam pembuatan cookies (Kartika, 1995), bolu (Atmojo, 2007), cracker (Driyani, 2007), dan biskuit (Muchtadi, 1992). Akan tetapi produkproduk menggunakan tepung terigu sebagai salah satu bahan bakunya. Oleh karena itu perlu adanya diversifikasi olahan tepung tempe yang lain tanpa menggunakan tepung terigu seperti snack bars.

Snack bars merupakan makanan ringan yang berbentuk batangan berbahan dasar sereal atau kacang-kacangan. Salah satu produk snack bars yang beredar di pasaran Indonesia berbahan dasar tepung kedelai dan buah-buahan asli yang dikeringkan. Produk snack bars yang telah mendapatkan patent dari US Patent terdapat dua paten yaitu snack bars dari selai kacang tanah dengan isian kacang tanah (US 2002/0051837 A1, May 2 2002) dan snack bars dengan laminasi (US 2009/0110780 A1, Apr.30 2009). Oleh karena itu pembuatan snack bars berbahan tepung tempe dan buah kering lokal dapat dikembangkan. Buah lokal yang berpotensi digunakan sebagai bahan campuran pembuatan snackbars adalah mangga dan salak.

Tiga konsep pangan, yaitu memproduksi pangan yang sehat, praktis dan enak menjadi tuntutan konsumen. Oleh 
karena itu perlu upaya formulasi snack bars tempe agar ketiga konsep pangan tersebut dapat terpenuhi. Tujuan penelitian ini adalah mengetahui karakteristik fisikokimia snack bars tempe dan mengetahui karakteristik organoleptik snack bars tempe.

\section{METODE PENELITIAN}

\section{Bahan}

Bahan utama yang digunakan dalam pembuatan snack bars adalah tempe yang dibeli dari produsen tempe "Samodra" di Mojosongo, buah mangga, dan buah salak yang dibeli di Pasar Gede Surakarta. Bahanbahan yang digunakan untuk analisis antara lain larutan $\mathrm{HCl} 0,02 \mathrm{~N}, \mathrm{H}_{2} \mathrm{SO}_{4}, \mathrm{HgO}$, larutan $\mathrm{NaOH}-\mathrm{Na}_{2} \mathrm{~S}_{2} \mathrm{O}_{3}, \quad \mathrm{~K}_{2} \mathrm{SO}_{4}$, $\mathrm{Na}_{2} \mathrm{~B}_{4} \mathrm{O}_{7} \cdot 10 \mathrm{H}_{2} \mathrm{O}, \quad \mathrm{H}_{3} \mathrm{BO}_{3}$, indikator (campuran 2 bagian metil merah 0,2\% dalam alkohol dan 1 bagian metilen blue $0,2 \%$ dalam alkohol), aquadest, petroleum ether, 2,2-diphenyl-1-picrylhydrazyl

(DPPH), ethanol, $\mathrm{Na}_{2} \mathrm{CO}_{3}$ alkali, Folin ciocalteu, dan fenol murni.

\section{Pembuatan Tepung Tempe}

Pembuatan tepung tempe didasarkan pada metode Syarief (1999) yang telah dimodifikasi untuk mendapatkan tepung tempe berkualitas baik. Tahap pembuatan tepung tempe terdiri dari blanching, pemotongan, pengeringan, penggilingan dan pengayakan. Proses blanching atau pemblansiran dilakukan dengan cara mencelupkan ke dalam air panas selama 10 menit. Pengecilan ukuran (pemotongan) dilakukan dengan cara tempe dipotong berbentuk segi empat dengan ukuran panjang 1 (satu) $\mathrm{cm}$, lebar 1 (satu) $\mathrm{cm}$ dan tebal $0,2 \mathrm{~cm}$. Pengeringan dilakukan dengan menggunakan cabinet dryer dengan suhu $60^{\circ} \mathrm{C}$ selama 6 jam. Penggilingan dilakukan dengan menggunakan blender. Pengayakan tempe dilakukan dengan menggunakan mesin pengayak. Tepung tempe yang bertekstur halus berukuran 80100 mesh.

\section{Pembuatan Buah Kering}

Pembuatan buah kering didasarkan pada metode Barta (2006). Tahapan-tahapan dalam pembuatan buah kering antara lain pembersihan, pencucian, pengirisan, dan pengeringan. Buah yang akan dikeringkan harus dibersihkan untuk menghilangkan kotoran pada buah. Pencucian dapat dilakukan sebelum pencucian ataupun setelah pencucian. pencucian harus dilakukan dengan air yang telah memenuhi standart sebagai air minum. Ukuran pengirisan adalah $1 \mathrm{x} 1 \mathrm{~cm}$. Pengeringan menggunakan cabinet dryer suhu $60{ }^{\circ} \mathrm{C}$ selama 4 jam.

\section{Pembuatan Snack Bars}

Pembuatan snack bars didasarkan pada beberapa resep yang kemudian dimodifikasi. Bahan-bahan ditimbang sesuai dengan formula yang akan dibuat. Tahap pertama dilakukan pencampuran antara margarin, gula halus dan garam. Setelah tercampur rata dilakukan penambahan telur dengan putih telur setengah dari jumlah telur, dan pengadukan sampai rata. Bahan terakhir yang ditambahkan adalah tepung tempe dan buah kering. Adonan ditata dalam loyang dan dioven pada suhu $120^{\circ} \mathrm{C}$ sampai berwarna kecoklatan. Variasi snackbars yang dihasilkan meliputi snackbars dengan bahan campuran tepung tempe dan buah kering (mangga dan salak). Perbandingan antara tepung tempe dan buah kering yang digunakan adalah 40:60, 50:50 dan 60:40.

\section{Analisis Karakteristik Fisikokimia dan Sensoris Snackbars}

Snack bars yang dihasilkan dilakukan analisa untuk mengetahui karakteristik fisikokimia dan sensorisnya. Karekteristik fisik (tekstur) dianalisa menggunakan Lyod Universal Testing Machine (Wijayanti, 2007). Sedangkan karakteristik kimia meliputi kadar air menggunakan metode thermogravimetri (Sudarmadji dkk, 2003), kadar abu dengan metode penetapan total abu (Apriyantono dkk,1989), kadar protein kjeldahl (Apriyantono dkk, 1989), kadar lemak metode ekstraksi soxhlet (Apriyantono dkk,1989), kadar karbohidrat by difference (Winarno, 2002), kadar serat metode uji total dietary fiber 991.43 (AOAC, 1996), aktivitas antioksidan DPPH (Subagio dan Morita, 2001), total fenol FolinCiocalteau (Senter, et. al., 1989), serta total 
kalori menggunakan alat Boom Calori. Karakteristik sensoris ditentukan dengan mengetahui tingkat kesukaan (hedonik) panelis menurut Kartika dkk (1988) pada parameter warna, aroma, rasa, tekstur dan oveall terhadap snackbars.

\section{Rancangan Percobaan}

Rancangan Penelitian menggunakan pola Rancangan Acak Lengkap (RAL) yang terdiri dari satu faktor, yaitu perbedaan formulasi antara tepung tempe dan buah kering dengan 3 kali ulangan sampel. Data hasil penelitian dianalisis dengan menggunakan ANOVA untuk mengetahui ada tidaknya perbedaan perlakuan variasi komposisi tepung tempe dan buah kering pada tingkat $\alpha=0,05$ untuk tiap variasi buah. Kemudian dilanjutkan dengan DMRT pada tingkat $\alpha$ yang sama.

\section{HASIL DAN PEMBAHASAN}

\section{Karakteristik Fisikokimia Snackbars Tempe}

Karakteristik fisikokimia snackbars dilakukan dengan mengetahui tekstur, kadar air, kadar abu, kadar protein, kadar lemak, kadar karbohidrat, kadar serat pangan, total kalori, total fenol, dan aktivitas antioksidan. Hasil karakteristik fisikokimia snackbars tempe dapat dilihat pada Tabel 1 .

Tekstur snackbars menunjukkan tingkat kekerasan. Semakin besar proporsi tepung tempe yang digunakan, tekstur snackbars yang dihasilkan semakin keras (kompak). Kadar air snackbars yang dihasilkan berkisar antara $15,11 \%-20,91 \%$. Semakin besar proporsi tepung tempe yang digunakan, kadar air snackbars yang dihasilkan semakin kecil. Semakin besar proporsi tepung tempe yang digunakan, kadar protein dan kadar lemak snackbars yang dihasilkan semakin besar. Kadar protein snackbars berkisar antara $15,87 \%$ $26,42 \%$ sedangkan kadar lemak berkisar antara $15,87 \%-24,88 \%$. Kadar karbohidrat snackbars berkisar antara 33,97\% - 45,27\% dan menunjukkan pola penurunan kadar karbohidrat dengan semakin besar proporsi tepung tempe. Kadar serat dan total fenol snackbars menunjukkan hasil yang hampir sama untuk tiap variasi buah dan komposisi. Kadar serat berkisar antara 15,84\% - 19,35\% sedangkan total fenol berkisar antara 1,30 $\mathrm{mg} / \mathrm{g}-3,48 \mathrm{mg} / \mathrm{g}$. Aktivitas antioksidan snackbars yang dihasilkan makin besar dengan semakin besarnya proporsi tepung tempe yaitu berkisar antara $39,64 \%$ $53,43 \%$. Total kalori snackbars berkisar antara 384,6 Kkal/100g - 502,38 Kkal/100g dan menunjukkan total kalori yang semakin besar dengan semakin besar proporsi tepung tempe yang digunakan.

Perbedaan kandungan gizi pada masing-masing snackbars dipengaruhi oleh kandungan gizi bahan baku serta proses pengolahan. Menurut USDA (2009), kadar air tempe adalah $54,9 \%$ dan kadar air buah mangga segar adalah 83,46 \%. Salak memiliki kadar air sebesar 78\% (USDA, 2010). Namun pada tempe apabila telah ditepungkan akan mengalami penurunan kadar air, karena dalam proses penepungan telah mengalami pengeringan, dan menurut Lowe (1989) kadar air untuk tepung berkisar antara 11\%-13\%. Pada buah setelah mengalami pengeringan kadar air juga akan mengalami penurunan. Penurunan kadar air ini dipengaruhi oleh banyak faktor, diantaranya yaitu besar kecilnya potongan buah, suhu pengeringan dan waktu pengeringan. Menurut Winarno dan Laksmi (1974) dalam Muchtadi (1997) kadar air buah kering berkisar antara $18 \%$ sampai 25 $\%$.

Tepung tempe mengandung berbagai mineral seperti $\mathrm{P}, \mathrm{Fe}, \mathrm{Ca}, \mathrm{Mg}, \mathrm{Na}, \mathrm{Cu}$ dan $\mathrm{Zn}$ yang cukup tinggi masing-masing sebesar 340,8; 10,4;149; 35; 7,5; 1,9, dan $1,3 \mathrm{mg} / 100 \mathrm{mg}$ (Astuti dkk, 1983) sedangkan mangga hanya mengandung $\mathrm{Ca}, \mathrm{Fe}$, dan $\mathrm{P}$ masing-masing sebesar 9,7;5,8; dan $0,1 \mathrm{mg} /$ $100 \mathrm{~g}$ bahan (Santosa, 2006). Menurut USDA (2009), mangga segar mempunyai kadar abu sebesar $0,36 \mathrm{~g} / 100 \mathrm{~g}$. Sementara salak memiliki kandungan mineral seperti $\mathrm{Ca}$ sebesar $38 \mathrm{mg} / 100 \mathrm{gr}, \mathrm{P}$ sebesar $31 \mathrm{mg} / 100 \mathrm{gr}$ dan $\mathrm{Fe}$ sebesar 3,90 mg/100gr (Direktorat Gizi, 1976).

Tepung tempe mempunyai kadar protein sebesar 46,1 \% (Astuti dkk, 1983) dan mangga mengandung protein sebesar $0,82 \mathrm{~g} / 100 \mathrm{~g}$ (USDA, 2009) atau 0,82\% 
Tabel 1. Karakteristik Fisikokimia Snackbars

\begin{tabular}{ccccccc}
\hline \multirow{2}{*}{ Karakteristik } & \multicolumn{3}{c}{ Mangga } & \multicolumn{3}{c}{ Salak } \\
\cline { 2 - 6 } & $40: 60$ & $50: 50$ & $60: 40$ & $40: 60$ & $50: 50$ & $60: 40$ \\
\hline Tekstur (N) & $36,35^{\mathrm{a}}$ & $46,46^{\mathrm{b}}$ & $58,23^{\mathrm{c}}$ & $109,28^{\mathrm{a}}$ & $182,11^{\mathrm{b}}$ & $228,05^{\mathrm{c}}$ \\
Kadar Air (\%) & $20,91^{\mathrm{a}}$ & $20,57^{\mathrm{a}}$ & $20,72^{\mathrm{a}}$ & $20,72^{\mathrm{c}}$ & $17,60^{\mathrm{b}}$ & $15,11^{\mathrm{a}}$ \\
Kadar Abu (\%) & $1,34^{\mathrm{a}}$ & $1,7^{\mathrm{b}}$ & $2,27^{\mathrm{c}}$ & $1,99^{\mathrm{a}}$ & $2,36^{\mathrm{b}}$ & $2,37^{\mathrm{b}}$ \\
Kadar Protein (\%) & $17,71^{\mathrm{a}}$ & $21,82^{\mathrm{b}}$ & $26,42^{\mathrm{c}}$ & $15,87^{\mathrm{a}}$ & $17,54^{\mathrm{a}}$ & $23,66^{\mathrm{b}}$ \\
Kadar Lemak (\%) & $15,68^{\mathrm{a}}$ & $17,14^{\mathrm{ab}}$ & $19,55^{\mathrm{b}}$ & $18,77^{\mathrm{a}}$ & $21,42^{\mathrm{b}}$ & $24,88^{\mathrm{c}}$ \\
Kadar Karbohidrat & $45,27^{\mathrm{b}}$ & $40,67^{\text {ab }}$ & $36,39^{\mathrm{a}}$ & $42,64^{\mathrm{c}}$ & $41,05^{\mathrm{b}}$ & $33,97^{\mathrm{a}}$ \\
$\begin{array}{c}\text { (\%) } \\
\text { Kadar Serat (\%) }\end{array}$ & $17,95^{\mathrm{a}}$ & $19,35^{\mathrm{b}}$ & $18,93^{\text {ab }}$ & $15,84^{\mathrm{a}}$ & $18,01^{\mathrm{a}}$ & $17,12^{\mathrm{a}}$ \\
Total Fenol (mg/g) & $1,30^{\mathrm{a}}$ & $1,75^{\mathrm{a}}$ & $3,48^{\mathrm{b}}$ & $1,13^{\mathrm{a}}$ & $2,39^{\mathrm{a}}$ & $2,88^{\mathrm{a}}$ \\
Aktivitas & $39,64^{\mathrm{a}}$ & $44,12^{\mathrm{b}}$ & $45,19^{\mathrm{b}}$ & $49,31^{\mathrm{a}}$ & $52,88^{\mathrm{a}}$ & $53,43^{\mathrm{a}}$ \\
Antioksidan (\%) & & & & & \\
Total Kalori & $384,6^{\mathrm{a}}$ & $430,5^{\mathrm{b}}$ & $442,7^{\mathrm{b}}$ & $455,77^{\mathrm{a}}$ & $461,71^{\mathrm{a}}$ & $502,38^{\mathrm{a}}$ \\
\hline Kkal/100g) & & & & &
\end{tabular}

Keterangan : Angka yang diikuti huruf yang sama pada tiap kolom menunjukkan tidak berbeda nyata pada $\alpha 5 \%$

sedangkan kandungan protein pada salak pondoh sebesar $0,4 \%$ (Direktorat Gizi, 1976). Tepung tempe mengandung lemak sebesar 22\% (Astuti et. al., 1983) sedangkan mangga mengandung lemak sebesar $0,38 \%$ (USDA, 2009) dan salak pondoh tidak memiliki kandungan lemak (Direktorat Gizi, 1976).

Pada penelitian ini kadar karbohidrat dihitung menggunakan metode $B y$ Difference, yaitu \% Karbohidrat $=100 \%-\%$ (protein + lemak + abu + air). Menurut USDA (2009), kandungan karbohidrat pada tempe yaitu $17 \%$ dan pada buah mangga yaitu $14,98 \%$. Buah salak mengandung karbohidrat sederhana (monosakarida) seperti glukosa dan fruktosa sebesar 20,9 gr/100 gram (Direktorat Gizi, 1976).

Tepung tempe mempunyai kandungan serat pangan sebesar 1,4\% (Astuti dkk, 1983) dan mangga mengandung serat pangan sebesar 1,6\% (USDA, 2009) serta buah salak memiliki kandungan serat pangan $1 \%$ (USDA, 2010). Proses pemanasan akan dapat merusak komponen serat pangan. Selama proses pembuatan snackbars terjadi dua kali pemanasan, yaitu pada saat pembuatan tepung tempe dan pemanggangan adonan snackbars. Pemanasan dapat menyebabkan komponen serat pangan akan mengalami degadasi sehingga pada saat dilakukan analisa serat pangan dengan menggunakan enzim dan senyawa asam dan basa komponen serat pangan akan terhidrolisis sehingga kadarnya semakin rendah (Indriyani, 2007).

Marsono dkk (2003) mengatakan bahwa kedelai mempunyai total fenol sebanyak $0,54 \mathrm{mg} / \mathrm{g}$ dan selama fermentasi kandungan total fenol ini semakin bertambah, sedangkan tempe mempunyai total fenol sebesar 2,857 mg/g (Dewi, 2010). Tempe memiliki kandungan senyawa fenol dalam bentuk isoflavon dan turunannya, sedangkan pada mangga tidak terdapat senyawa antioksidan yang bersifat fenolik. Sebagian besar antioksidan mangga berupa vitamin C yaitu sebesar 36,4\% (USDA, 2009). Buah salak memiliki total fenol 0,46 $\mathrm{mg} / 100 \mathrm{gr}$ (Kurniawati, 2010). Dari hasil penelitian yang diperoleh nilai total fenol pada snack bars berbeda jauh dengan nilai total fenol pada tempe. Hal ini dikarenakan pada pengolahan tempe menjadi tepung tempe mengalami beberapa perlakuan yang melibatkan panas dan kontak dengan udara yaitu blanching dan pengeringan. Sementara fenol adalah senyawa yang mudah teroksidasi apabila terkena panas dan kontak dengan udara. Selain itu setelah 
Tabel 2. Karakteristik Sensoris Snackbars

\begin{tabular}{ccccccc}
\hline \multirow{2}{*}{ Parameter } & \multicolumn{3}{c}{ Mangga } & Salak \\
\cline { 2 - 7 } & $40: 60$ & $50: 50$ & $60: 40$ & $40: 60$ & $50: 50$ & $60: 40$ \\
\hline Warna & $5,70^{\mathrm{b}}$ & $4,65^{\mathrm{a}}$ & $5,05^{\mathrm{a}}$ & $3,40^{\mathrm{a}}$ & $4,20^{\mathrm{b}}$ & $5,40^{\mathrm{c}}$ \\
Aroma & $5,75^{\mathrm{c}}$ & $5,05^{\mathrm{b}}$ & $4,00^{\mathrm{a}}$ & $3,40^{\mathrm{a}}$ & $4,20^{\mathrm{b}}$ & $5,40^{\mathrm{c}}$ \\
Rasa & $4,10^{\mathrm{b}}$ & $5,05^{\mathrm{b}}$ & $3,30^{\mathrm{a}}$ & $5,15^{\mathrm{b}}$ & $4,45^{\mathrm{a}}$ & $4,65^{\mathrm{b}}$ \\
Tekstur & $5,25^{\mathrm{b}}$ & $5,45^{\mathrm{b}}$ & $4,25^{\mathrm{a}}$ & $4,15^{\mathrm{a}}$ & $4,40^{\mathrm{a}}$ & $5,20^{\mathrm{b}}$ \\
Overall & $5,30^{\mathrm{a}}$ & $5,15^{\mathrm{a}}$ & $5,05^{\mathrm{a}}$ & $4,60^{\mathrm{a}}$ & $4,45^{\mathrm{a}}$ & $5,00^{\mathrm{a}}$ \\
\hline
\end{tabular}

Keterangan : Angka yang diikuti huruf yang sama pada tiap kolom menunjukkan tidak berbeda nyata pada $\alpha 5 \%$

terbentuknya adonan snackbars, dilakukan proses pematangan menggunakan oven dengan suhu yang tinggi yaitu $120^{\circ} \mathrm{C}$. Dari beberapa tahap proses pengolahan tersebut maka berefek pada penurunan total fenol yang cukup signifikan.

Mangga mempunyai senyawa antioksidan yang sebagian besar berupa vitamin C yaitu sebesar $36,4 \mathrm{~g} / 100 \mathrm{~g}$ (USDA, 2009) atau 36,4\%, sedangkan kadar antioksidan pada tempe sebesar 45,75\% (Hayati, 2010). Antioksidan pada buah salak yang berbentuk vitamin $\mathrm{C}$ sebesar 129,34 $\mathrm{mg} / 100$ gr (Kurniawati, 2010).

Menurut USDA (2009) kalori pada tempe yaitu $199 \mathrm{kkal} / 100 \mathrm{~g}$ dan pada buah mangga yaitu $60 \mathrm{kkal} / 100 \mathrm{~g}$. Kandungan kalori pada salak sebesar $0,77 \mathrm{kal} / \mathrm{gram}$ (Eisai, 1996). Total kalori pada buah tepung tempe dan buah mangga tidak begitu tinggi. Namun total kalori pada snackbars memiliki nilai yang lebih tinggi. Tingginya total kalori pada snackbars merupakan pengaruh dari kandungan kalori bahan-bahan pendukung yang digunakan. Dimana bahan pendukung yang digunakan pada ketiga formulasi memiliki berat dan jenis yang sama. Berdasarkan tabel kalori makanan dalam 'Panduan Kesehatan Keluarga' (Eisai, 1996) bahan-bahan pendukung yang digunakan memiliki pengaruh besar terhadap nilai total kalori snackbars yaitu, $30 \mathrm{~g}$ margarine dengan kalori $720 \mathrm{kkal} / 100 \mathrm{~g}, 1$ butir telur ayam dengan kalori $162 \mathrm{kkal} / 100 \mathrm{~g}$ dan $30 \mathrm{~g}$ gula pasir dengan kalori $364 \mathrm{kkal} / 100 \mathrm{~g}$.

\section{Karakteristik Sensoris Snackbars Tempe}

Karakteristik sensoris diketahui dengan melakukan uji sensoris. Uji sensoris pada suatu produk memiliki peran yang sangat penting, berkaitan dengan penerimaan konsumen terhadap produk yang dihasilkan. Uji sensoris dilakukan dengan uji kesukaan skoring oleh 20 orang panelis tidak terlatih. Parameter yang digunakan untuk uji sensoris yaitu warna, aroma, rasa, tekstur dan overall. Penerimaan panelis terhadap snackbars dapat dilihat pada Tabel 2.

Berdasarkan Tabel 2 terlihat bahwa pada parameter warna, panelis menunjukkan tingkat kesukaan antara agak tidak suka sampai agak suka. Pada sampel snackbars dengan bahan buah mangga kering dengan komposisi 40:60 lebih disukai panelis daripada komposisi yang lain. Sedangkan pada snackbars dengan buah salak kering, komposisi yang paling disukai adalah 60:40. Warna yang disukai oleh panelis adalah warna snackbars yang kuning kecoklatan sedangkan snackbars dengan warna coklat kehitaman atau kuning pucat lebih tidak disukai panelis.

Semakin besar proporsi buah yang digunakan maka akan menghasilkan snackbars yang lebih disukai panelis pada parameter aroma kecuali pada snackbars dengan buah salak. Karena dengan semakin besar buah kering (mangga) yang digunakan maka snackbars yang dihasilkan mempunyai aroma khas buah campurannya. Sedangkan salak yang relatif tidak beraroma menyebabkan aroma netral pada snackbars yang dihasilkan.

Rasa snackbars yang disukai oleh panelis ditunjukkan oleh sampel snackbars dengan proporsi buah kering yang lebih banyak. Panelis memberikan tingkat kesukaan antara agak tidak suka sampai agak suka pada parameter rasa. Semakin besar proporsi buah yang digunakan juga menghasilkan snackbars yang lebih disukai 
panelis pada parameter tekstur kecuali pada snackbars dengan buah salak.

Secara keseluruhan panelis lebih menyukai snackbars dengan komposisi 40:60 pada snackbars dengan bahan buah mangga kering. Sedangkan pada snackbars dengan buah salak secara keseluruhan panelis lebih menyukai snackbars dengan komposisi 60:40.

\section{KESIMPULAN}

Karakteristik fisikokimia dan sensoris snackbars dengan bahan tepung tempe dan buah kering (mangga dan salak) menunjukkan hasil yang bervariasi. Secara umum dengan semakin besar proporsi tepung tempe yang digunakan maka menghasilkan snackbars yang mempunyai tekstur (tingkat kekerasan), kadar abu, kadar protein, kadar lemak, aktivitas antioksidan serta total kalori yang lebih besar. Sedangkan kadar air dan kadar karbohidrat semakin rendah pada snackbars dengan proporsi tepung tempe lebih besar. Kadar serat serta total fenol snackbars yang dihasilkan tidak berbeda nyata antar variasi komposisi. Secara keseluruhan panelis lebih menyukai snackbars dengan komposisi 40:60 pada snackbars dengan bahan buah mangga kering, serta komposisi 60:40 pada snackbars dengan buah salak.

\section{DAFTAR PUSTAKA}

Adam, James B. 2007. Summary of Biomedical Treatments of Autism. ARI Publication 40.

Astuti, M., A. Meliala., FS Dalais and M LWahlqvist. 2000. Tempe, a nutritious and healthy food from Indonesia Asia Pacific J Clin Nutr (2000) 9(4): 322325

Astuti, Mary dan Hardiman. 1983. Tepung Tempe, Pemahaman Sifat-Sifat dan Penyesuaian Penggunaannya. Laporan Penelitian Fakultas Teknologi Pertanian Universitas Gajah Mada.

Astuti, Mary., Meliala, Andreanyta., Fabien, Dalais., wahlq, Mark. 2000. Tempe a nutritious and healthy food from
Indonesia. Asia Pasific J Ciin Nutr(2000) 9(4): 322-325.

Atmojo, LD. 2007. Pengaruh subtitusi tepung tempe dan penggunaan minyak goreng terhadap kualitas organoleptik dan nilai gizi bolu kukus. Skripsi Jurusan Teknologi Jasa dan Produksi, Fakultas Teknik Universitas Negeri Semarang.

Barta, Jozsef. 2006. Fruit Drying Principles dalam Handbook of Fruits and Fruit Processing. Blackwell Publishing. USA.

Dewi, Intan Wahyu R. 2010. Karakteristik Sensori, Nilai Gizi dan aktivitas Antioksidan Tempe Kacang Gude (Cajanus cajan (L.) Millsp.) dan Tempe Kacang Tunggak (Vigna unguiculata (L.) Walp.) dengan Berbagai Variasi Waktu Fermentasi. Skripsi.

Direktorat Gizi. 1976. Daftar Komposisi Bahan Makanan. Departemen Kesehatan. Jakarta.

Driyani, Y. 2007. Biscuit crackers substitusi tepung tempe kedelai sebagai alternatif makanan kecil bergizi tinggi. Skripsi Jurusan Teknologi Jasa dan Produksi, Fakultas Teknik Universitas Negeri Semarang

Eisai. 1996., Panduan Kesehatan Keluarga. Human Health Company.

Hayati, Eni Nur. 2010. Kajian aktivitas antioksidan dan kandungan Dietary fiber pada tempe berbahan baku kedelai / beras dengan penambahan angkak serta variasi Lama fermentasi. Skripsi.

Kartika, Bambang, Hastuti, Pudji dan Suparnoto, Wahyu. 1988. Pedoman Uji Inderawi Bahan Pangan. PAUP UGM. Yogyakarta.

Kartika, H. E. 1995. Pengaruh Penambahan Tepung Tempe Terhadap Sifat Cookies. Skripsi. FTP UGM. Yogyakarta.

Kasmidjo, R. 1996. Tempe, Mikrobiologi dan Biokimia Pengolahan serta 
Pemanfaatan. PAU Pangan dan Gizi, UGM, Yogyakarta.

Kasmidjo, R.B Dr. Ir. 1990. Tempe Mikrobiologi dan Biokimia Pengolahan serta Pemanfaatannya. Yogyakarta: Pusat Antar Universitas Pangan dan Gizi UGM.

Kurniawati, Dian. 2010. Komponen Bioaktif dan Kapasitas Antioksidan Buah Salak (Salacca Edulis Reinw) Kultivar Pondoh, Nglumut dan Bali. Skripsi. Program Studi Teknologi Hasil Pertanian. Fakultas Pertanian. Universitas Sebelas Maret. Surakarta.

Lowe, Belle. 1986. Experimental cookery from the chemical and physical standpoint. 3rd ed. Wiley, Chapman and Hall. New York.

Muchtadi, D., M. Supriyanto, Y. Murfedi. 1992. Sifat Fungsional Dan Nilai Gizi Tepung Tempe Serta Pengembangan Produk Olahannya Untuk Golongan Rawan Gizi. Laporan penelitian IPB.Bogor.

Santoso. 2005. Teknologi Pengolahan Kedelai (Teori Dan Praktek). Fakultas Pertanian Universitas Widyagama Malang.

Sarwono, B. 1988. Membuat Tempe Dan Oncom. Jakarta: Penebar Swadaya

Subagio, A. dan Morita N. 2001. No Effect of Esterification with Fatty Acid on Antioxidant Activity of Lutein. Food Rest Int.

Sudarmadji, S, Bambang Haryono, dan Suhardi. 1989. Analisa Bahan Makanan dan Pertanian. Liberty. Yogyakarta.

Syarief, Rizal, dkk. 1999. Wacana Tempe Indonesia. Surabaya : Universitas Katolik Widya Mandala.

US Patent Application Publication No. US2002/0051837 A1, May 22002

US Patent Application Publication No. US2009/0110780 A1, Apr.30 2009
USDA National Nutrient Data Base. 2010. Snake Fruit Nutrients. United States Department of Agriculture.

USDA. 2009. National Nutrient Database for Standard Reference, Release 22(2009). http://www.nal.us da.gov/fnic/foodcomp/cgibin/list_nutedit. pl. 